\title{
NORTH AND SOUTH FORKS OF THE SUN RIVER FLUVIAL ARCTIC GRAYLING REINTRODUCTION PLAN
}

\author{
Prepared By \\ James P. Magee \\ For \\ Montana Fish, Wildlife, and Parks \\ and \\ Fluvial Arctic Grayling Workgroup
}




\section{INTRODUCTION}

Arctic grayling (Thymallus arcticus) were once widespread in the Missouri River drainage upstream of Great Falls. Grayling were endemic to the Missouri River and its tributaries: the Smith, Sun, Madison, Gallatin, Jefferson, Beaverhead, and Big Hole rivers. During the 20th century, the range of fluvial, or river-dwelling, grayling became restricted to the Big Hole River, about $4 \%$ of its native range (Kaya 1992a). The impacts of climatic change, introductions of non-native fishes, habitat alteration, and overharvest by anglers are considered primary reasons for the decline of fluvial grayling (Vincent 1962, Kaya 1992a).

The Big Hole River grayling population declined in abundance through the mid-1980's to low levels. Concern for the population resulted in formation of the interagency Fluvial Arctic Grayling Workgroup (FGW) to coordinate restoration of fluvial grayling in the Big Hole River and throughout native range in Montana. A plan was developed to recover Arctic grayling with a goal of "at least five stable, viable populations distributed among at least three of the major river drainages... within the historic range of Montana grayling... (FGW 1995)."

The North and South forks of the upper Sun River, above Gibson Reservoir, were identified by Kaya (1992b) as candidate sites for introducing grayling. These streams were most likely historically barren of fish due to a barrier falls located in a high gradient gorge, which is now the location of the Diversion Dam constructed from 1912 to 1914. Historically, grayling were present in the main 
Sun River below Diversion Dam. Stocking of rainbow and cutthroat trout in the North and South forks began as early as 1904 (MFWP Files). The North and South forks of the sun River are of particular interest because they provide relatively long unimpeded river reaches, a basic requirement of fluvial grayling habitat. Approximately 13 miles of the South Fork, and 21 miles of the North Fork may encompass suitable habitat for fluvial grayling with respect to pool habitats, adequate flow, temperature, and geomorphology. This document is the Reintroduction Plan required for grayling reintroductions by the FGW in the Montana Fluvial Arctic Grayling Restoration Plan (FGW 1995).

Restoration Goals, Objectives, and Scope

The restoration goal is to introduce fluvial Arctic grayling into the North and South forks of the Sun River, beginning in 1998, to establish a stable, naturally reproducing population above Gibson Reservoir by 2006. Objectives of the reintroduction are to: 1) Monitor survival, movements and densities of introduced grayling to determine factors affecting success of reintroduction, and

2) Document natural reproduction by 2006 ,

3) Attain stable to increasing population densities in sampling sections where natural reproduction equals or exceeds annual mortality for three consecutive years.

It is recognized that the success of any reintroduction will hinge upon a complex set of environmental variables beyond the control of resource management. Thus, it is important to define 
the scope of time that will be dedicated to the effort. If limiting factors are identified that will realistically preclude founding of a self-sustaining population, the project will cease. Therefore, if natural reproduction is not documented by October, 2006 and data do not demonstrate a likelihood of correcting limiting factors, the project will be discontinued and resources will be diverted to alternative reintroduction sites. Monitoring until 2006 will allow MFWP to evaluate the establishment of a self sustaining grayling population based on 2 generations of grayling since the last stock date in 2001.

IDENTIFICATION OF ISSUES AND SUITABILITY FOR GRAYLING

A number of issues must be addressed to successfully plan and implement the reintroduction program. Issues were identified by representatives of the FGW, U. S. Forest Service Lewis and Clark National Forest (USFS), Montana Fish, Wildlife, and Parks (MFWP), U.S. Fish and Wildlife Service (USFWS), and interested publics at an open meetings held in Augusta, on May 11, 1998 and through written comments.

\section{Endangered Species Act}

The U. S. Fish and Wildlife service (USFWS) formerly classified fluvial Arctic grayling in Montana as "Category 1" under the Endangered Species Act; that is, enough substantial information exists to support a proposal to list it as threatened or endangered (USFWS 1991). This category was renamed "Candidate" in February 1996 (USFWS 1996). A petition to list fluvial Arctic grayling as endangered was submitted in October, 1991 (USFWS 1993). A recent 
finding on the petition recommended that listing fluvial Arctic grayling was "warranted, but precluded" by higher priority listing actions (USFWS 1994).

The potential for listing fluvial Arctic grayling as endangered was a primary concern of local residents voiced at a public meeting and through written comments. Introduction of candidate species to the North and South forks of the Sun River was perceived to potentially affect angling opportunities, regulations, recreation, and land use on public and private lands. However, a recent Memorandum of Agreement between USFWS and MFWP may alleviate many of the concerns as to the affects of a potential listing.

The Memorandum of Agreement was developed to sustain efforts to protect and restore fluvial grayling in the Big Hole River while expanding a program to reestablish additional populations. This agreement, signed in February 1996, includes a provision that, "By the year 2000, a minimum of five ...reintroductions will be in progress...within the historic range (MFWP Files)." The upper sun River introduction would be included to fulfill this requirement along with other proposed reintroductions. The goal of the agreement is to restore fluvial grayling to a level such that listing under the Endangered Species Act is unnecessary. Progress toward establishment of a viable population of fluvial grayling in the upper forks of the Sun River would be an important step toward fulfilling the terms of the agreement, achieving grayling restoration, and precluding the need to list. In the event that terms of the agreement are not met, a status review would be 
initiated to re-determine the necessity of listing in 2003 .

Local interested parties were concerned that if the Arctic grayling were eventually listed as an Endangered Species the USFWS may close the river to recreational fishing. In 1996, the USFWS adopted a policy to address the conservation needs of species listed under the Endangered Species Act while providing for the continuation and enhancement of recreational fisheries. This policy is intended to minimize and resolve conflicts between the implementation of the Endangered Species Act and activities to enhance recreational fishery resources and fishing opportunities. The USFWS may draft a Special Rule when a species is listed as an Endangered species. This rule could allow incidental catch of the listed species as long as it follows MFWP regulations. In the event the grayling is listed, the USFWS Montana Field office envisions a special rule would be issued to ensure the continuation of a recreational fishery in the North and South forks of the Sun River (Lori Nordstrom, USFWS, Personal Communication). Such a rule has been adopted for the recently listed bull trout. The rule states that fishing conducted in accordance to MFWP regulations is not considered a violation of the Endangered species Act. The rule even allows for fishing specifically for bull trout if legal according to state regulations.

Further, when the Arctic grayling population in the Big Hole River declined drastically in the mid 1980's, MFWP biologists were concerned that the effects of angling could be a limiting factor for the Big Hole population. A catch and release regulation was 
put into effect for grayling in 1988. However, it was unclear whether this regulation was sufficient to protect the declining population. To assess the potential effects of angling, a study was initiated to determine mortality rates due to hooking. Arctic grayling were captured using various types of tackle (flies, lures, bait, barbed and barbless hooks) and held in a live car to assess hooking mortality. Arctic grayling were found to be very resilient with low hooking mortality of $1.4 \%$ (MFWP Files). It was concluded the population was sufficiently protected under the current catch and release regulations.

The resilience of grayling to hooking mortality, and the USFWS adopted policy, and ability to adopt special Rules should allow for continued angling opportunities in the North and South forks of the Sun River.

\section{Public Land Management}

The proposal sites are totally within public lands managed by the Lewis and Clark National Forest. The North Fork (drainage area 258 square miles) flows through the Bob Marshall Wilderness until approximately one mile above Gibson Reservoir where it enters Lewis and Clark National Forest. The South Fork (drainage area 252 square miles) headwaters are located in the Scapegoat Wilderness, and thereafter flows through sections of Lewis and Clark National Forest and the Bob Marshall Wilderness before its confluence with the North Fork at Gibson Reservoir. All lands surrounding both forks are managed for wilderness or primitive use. Approximately 5955 recreational use days for the North Fork and 7855 for the 
South Fork were estimated for 1997 (USFS Files). The primary recreation includes; hunting, fishing, hiking, backpacking and horse riding. Anglers comprise between $25-50 \%$ of these visitor use days (USFS Files). There are approximately 5-10 outfitted angler companies using the North and south forks during summer months (USFS Files). Concerns were voiced that introducing grayling may impact private and outfitted angling opportunities and regulations. The primary concerns, relating to the Endangered Species Act, are addressed above. No additional legal protection would be provided to grayling, other than angling regulations. Statutes protecting grayling and their habitat in the upper sun River would include laws already in effect, regardless of presence or absence of grayling.

Additional concerns were voiced about the effects grayling could have on irrigation withdrawal and water management on the main Sun River and its associated dams, canals, diversions, and reservoirs if they moved into these systems. It is unlikely that grayling will migrate in large numbers over Gibson Dam, survive predation, fluctuating water and temperature regimes to establish natural reproducing populations. These areas are outside of the designated reintroduction area. Under the current status, grayling will be protected under catch-and-release regulations and no further fisheries management for grayling will be implemented. Grayling would have to survive under the existing conditions. In the event fluvial Arctic grayling are listed under the Endangered Species Act, the impact on irrigation in the sun River Basin would 
depend on a variety of issues. If the mainstem sun River was determined to be an appropriate location for recovery efforts, if necessary, the USFWS, in cooperation with the state, would work with irrigators and water managers to arrive at a compromise that provides for conservation of grayling and the needs/rights of the irrigators (Lori Nordstrom, USFWS, Personal communication). Cooperative efforts such as these have been highly successful in the Big Hole River Basin.

\section{Fisheries Management}

The upper forks of the Sun River support wild, resident game fish populations of rainbow trout (oncorhynchus mykiss), rainbowcutthroat hybrids, and brook trout (Salvelinus fontinalis). The only resident non-game species include mottled sculpin (Cottus bairdi), and an occasional white sucker (Catostomus commersoni). The Gibson Reservoir supports a rainbow trout fishery. An estimated 2,031 angler-days were exerted in the North Fork, 1,062 angler-days in the South Fork, and 1,813 angler days in Gibson Reservoir in 1995 (MFWP 1996). For comparison, in mid reaches of the Big Hole River where rainbow trout are the primary game species, 31,688 angler-days were sustained in 1995 (MFWP 1996). Arctic grayling coexist with rainbow trout in these reaches.

Gamefish populations in the North and south forks are monitored by hook and line \snorkeling mark-recapture surveys. A 1.3 mile section in the North Fork, and 1.0 mile section in the South Fork have been monitored annually since 1990 (Figure 1). Densities of $8 \mathrm{inch}$ and longer rainbow/cutthroat trout in the South 
Fork Section have ranged from 425 per mile to 674 per mile between 1990 and 1997. In the North Fork, densities have ranged from 508 per mile to 976 per mile (Table 1), (MFWP Files). Low numbers of brook trout were also sampled in both sections.

Kaya (1992b) expressed concern that the presence of nonnative fishes in the upper forks of the sun River may hinder success of the reintroduction. In the Big Hole River, densities of grayling are lowest where brown and rainbow trout densities are highest. However, grayling can coexist with rainbow trout at lower densities. Grayling are aggressive fish and have been observed to successfully defend territories against similar-sized rainbow trout (MFWP Files). However, interference competition occurs at some threshold of rainbow trout densities. At this point grayling spend more energy defending focal positions than they acquire feeding, resulting in an energy deficit and limited densities and survival. Based on coexisting populations in the Big Hole River this density threshold appears to be somewhere between 500-1000 rainbow trout per mile. However, grayling do coexist in reaches with moderate densities of rainbow trout. For example, in the sportsmans section of the Big Hole River, in 1997, age 1+ rainbow trout densities were 257 per mile, and Arctic grayling 73 per mile (Magee and Byorth 1998). In Deep Creek, a tributary of the Big Hole River, age 1+ grayling coexist successfully with rainbow trout densities from 300-400 per mile (Byorth 1994, Byorth 1996, Magee and Byorth 1998). In these sections rainbow trout densities from 1993 to 1997 range from 3.5 to 9.0 times greater than Arctic grayling (Byorth 

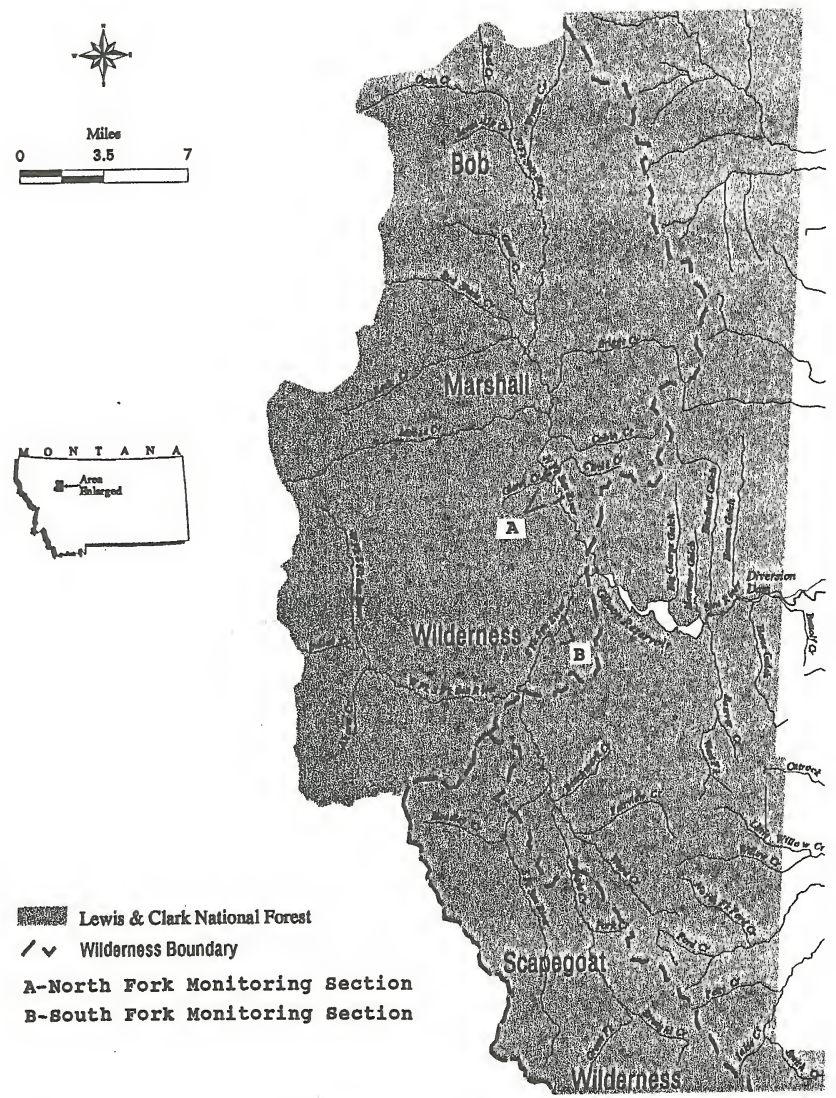

Wewis \& Clark National Forest

Iv Wildernoss Boundary

A-North Fork Monitoring section

B-south Fork Monitoring section

Figure 1. Map of the North and South Forks of the Sun River showing current MFWP monitoring sections. 
Table 1. Rainbow ( $R B$ ), rainbow-cutthroat hybrid ( $R B$ x CT), Age 2t, $>8$ inches, population densities in MarklRecapture sampling sections of the South and North forks of the Sun River, Montana.

\begin{tabular}{|c|c|c|c|c|}
\hline Sampling section & $\begin{array}{c}\text { River } \\
\text { Mile }\end{array}$ & Year & $\begin{array}{c}\text { Abundance } \\
(\# / \mathrm{mi})\end{array}$ & Species \\
\hline \multirow[t]{8}{*}{ South Fork } & 2.0 & 1990 & 674 & RB, RB $\times C T$ \\
\hline & 2.0 & 1991 & 715 & RB, RB $\times C T$ \\
\hline & 2.0 & 1992 & 492 & RB, RB $x$ CT \\
\hline & 2.0 & 1993 & 425 & RB, $\mathrm{RB} \times \mathrm{CT}$ \\
\hline & 2.0 & 1994 & 571 & $R B, R B \times C T$ \\
\hline & 2.0 & 1995 & 485 & $R B, R B \times C T$ \\
\hline & 2.0 & 1996 & 671 & $\mathrm{RB}, \mathrm{RB} \times \mathrm{CT}$ \\
\hline & 2.0 & 1990 & 454 & $\mathrm{RB}, \mathrm{RB} \times \mathrm{CT}$ \\
\hline \multirow[t]{8}{*}{ North Fork } & 4.5 & 1990 & 976 & $\mathrm{RB}, \mathrm{RB} \times \mathrm{CT}$ \\
\hline & 4.5 & 1991 & 458 & $\mathrm{RB}, \mathrm{RB} \times \mathrm{CT}$ \\
\hline & 4.5 & 1992 & 454 & $\mathrm{RB}, \mathrm{RB} \times \mathrm{CT}$ \\
\hline & 4.5 & 1993 & 554 & $\mathrm{RB}, \mathrm{RB} \times \mathrm{CT}$ \\
\hline & 4.5 & 1994 & 596 & $\mathrm{RB}, \mathrm{RB} \times \mathrm{CT}$ \\
\hline & 4.5 & 1995 & 596 & $\mathrm{RB}, \mathrm{RB} \mathrm{X} \mathrm{CT}$ \\
\hline & 4.5 & 1996 & 706 & $R B, R B \times C T$ \\
\hline & 4.5 & 1997 & 508 & $\mathrm{RB}, \mathrm{RB} \times \mathrm{CT}$ \\
\hline
\end{tabular}

1994, Byorth 1995, Byorth and Magee 1996, Byorth 1997, Magee and Byorth 1998). Established resident species may influence survival of stocked grayling through predation and competition for food and space. Rainbow trout densities in the North Fork and South Fork are at or near the threshold derived from Big Hole River studies. A valid concern is that planted grayling may not be successful in competing with the already established rainbow trout. 
The introduction of hatchery-reared fish may affect resident populations through interruption of social structures (Vincent 1987, Bachman 1982). However, historical and present coexisting populations suggest grayling, if successful, will establish populations at lower densities than rainbow trout, and rainbow trout populations are unlikely to decline due to the presence of Arctic grayling. The affects of resident populations and stocked grayling on each other will be monitored.

Angling regulations in the upper Sun Rivers will not be adjusted to protect grayling. Currently, grayling are managed under catch-and-release-only regulations in Montana streams. Current regulations on rainbow/cutthroat in the upper forks of the Sun River (limited to 3 fish daily only 1 over 12 inches in possession) will remain unchanged after introductions commence. similarly, fishing regulations in the reservoir will not be adjusted with respect to rainbow trout.

The goal of the introduction is specifically to establish a fluvial grayling population in the North and South forks above Gibson Reservoir. The presence of Gibson Reservoir may encourage introduced grayling to adapt to a lacustrine environment with adfluvial spawning behavior (Kaya 1992b). That is, that grayling may assume residence in the reservoir and enter the river only to spawn. Gibson Reservoir will be monitored to assess development of an adfluvial population.

Similarly, grayling may spill over Gibson Dam into the Diversion Lake and possibly the main sun River and associated 
diversions. These areas are outside of the designated reintroduction area. While grayling will be protected under catchand-release regulations, no further fisheries management for grayling will be exerted in Diversion Lake or below in the Sun River drainage.

An additional issue is the impact planted grayling could have on the grayling population of the sunnyslope Canal. Genetic analysis indicates this population is distinct from both lacustrine and fluvial grayling in Montana. This population has most likely gone through a genetic bottleneck due to limited numbers of reproducing adults under harsh environmental conditions (Robb Leary, University of Montana, Personal Communication). The possibility exists that grayling may migrate over Gibson Dam and enter the Pishkun Canal, navigate into Pishkun Reservoir and enter the Sunnyslope Canal. A screen at the Pishkun Reservoir outlet will prevent age 1+ and larger fish from entering the sunnyslope Canal. Young of the year ( $<6^{\prime \prime}$ ) grayling may be able to penetrate the screen, however, it is unlikely that large numbers would move over Gibson Dam, navigate approximately 14 miles through Pishkun Canal and Reservoir, and avoid likely predation from rainbow trout and Northern pike (Esox lucius), and survive to spawn with Sunnyslope canal grayling. In the unlikely event introduced grayling do manage to successfully spawn with sunnyslope Canal grayling, the genetic makeup of fluvial grayling should not negatively affect this unique population and fluvial genes may increase genetic vigor (Robb Leary, University of Montana, Personal 
Communication) .

Whirling Disease

Presence of the myxosporean parasite Myxobolus cerebralis and symptoms consistent with whirling disease have been documented in the Sun River drainage. Samples taken in 1997 from brown and rainbow trout on the Sun River near Fort Shaw, and Elk Creek near Augusta were confirmed to be infected by the parasite. A sample taken in the Alkali Flats area was suspect. A limited sample taken from Gibson Reservoir at the confluence of the North and South forks was negative, as well as fish tested in the Mill coulee area (MFWP files). Further whirling disease research by MFWP is scheduled for the main Sun River in the summer of 1998.

Recent studies indicate grayling are highly resistant to whirling disease. The presence of the parasite in the basin has been documented but the extent is still largely unknown. Unimpacted Rocky Mountain streams that have their normal, highly diverse insect communities intact provide poor Tubifix tubifix habitat and are considered low risk areas to the disease (World Wide Whirling Worm Web: http://rivers.msu.montana.edu/dlg/ aim/annelid/whirling.html). The headwater streams of the North and South forks may fall into this category, however, the presence of the disease in the basin certainly puts these streams at some risk. Densities of the intermediate host, Tubifex spp. worms, have not been sampled. Hence, the potential for proliferation is unknown. In the event whirling disease becomes established in the North and South forks it should not become a limiting factor to 
Arctic grayling because of their resistance to the disease.

Habitat and Biological suitability

Habitat analysis suggests the North and South forks encompass physical habitats required by fluvial grayling. Fluvial Arctic grayling prefer clear, cool water with intermediate gradients and velocities. In Montana, grayling historically inhabited waters with gradients less than $1 \%$, velocities of 1-2 feet per second, and pools or runs greater than $1.6 \mathrm{ft}$ in depth (Kaya 1992b). Approximately 13 miles in the south Fork (mean gradient $0.6 \%$ ), and 21 miles in the North Fork (mean gradient $0.7 \%$ ) contain habitats with respect to pools, runs, velocities, and depths, within the range that fluvial grayling have historically inhabited in Montana. Long unimpeded reaches of the North and south forks may be important for seasonal movements. Grayling in the Big Hole River are known to travel over 50 miles to spawning, summer, and overwintering habitats (Shepard and Oswald 1989).

Geology of the North Fork and South fork of the Sun River is primarily synclines of shales, mudstones and sandstone sequences. The South Fork also contains some outcroppings of limestone and igneous rocks. There is limited water quality data on either fork. Water quality data taken in 1960 on the North and South forks indicate $\mathrm{pH}$ from 7.8-8.1, total dissolved solids from 34-180 ppm, and turbidity ranging from $0.30-1.80$ (MFWP Files). Mean specific conductance on the North Fork in August/September from 1989-1993 
averaged $286 \mu$ mhos/Cm (USGS 1989-1993). Water chemistry and consequently the biological productivity in both forks may affect survival of stocked grayling. Invertebrate densities have not adequately been sampled in either fork. Visual observations of little periphyton growth and macrophyte beds indicate low productivity in both forks. This suggests grayling may establish a self sustaining population at lower densities than the Big Hole River.

The hydrograph and substrate analysis of the forks of the Sun Rivers reflects suitability for grayling spawning. Visual surveys of the North and south forks indicate ample spawning gravels. Grayling commonly spawn on freshly eroded and deposited gravels, generally after lowland runoff in early spring. Review of flow records from a U.S. Geological survey (USGS) gaging station 1 mile upstream from Gibson Reservoir on the North Fork indicates a spring hydrograph similar to the upper Big Hole River. Historic records indicate winter base flows in the North Fork averaged 67 cfs (USGS 1911-1912, 1945-1968 reviewed in USGS 1993). Lowland runoff typically increased flows to over $1000 \mathrm{cfs}$ in mid-April and returned to around 500 cfs early May (USGS 1989-1993). Grayling typically spawn, incubate, and emerge in the Big Hole River during this period, prior to highland runoff. Highland runoff generally begins in the Big Hole and the forks of the sun River in mid-late May and persists into June. This similarity in flow patterns suggests that the upper sun Rivers will provide suitable flow conditions for spawning grayling. However, the gradient of the 
South Fork $(0.6 \%)$ and North Fork $(0.7 \%)$ is slightly greater than typical spawning reaches of the Big Hole River: ranging 0.26 to $0.56 \%$.

While the upper Big Hole River was plagued by severe drought conditions between 1987 and 1994, the North Fork of the Sun River maintained suitable flows. In the Big Hole River between 1988 and 1995 mean monthly flows ranged from 58.7 to $85.8 \%$ of long-term (50year) average. In contrast, mean monthly flows of the North Fork ranged from 78 to $190 \%$ of long-term norms from 1989 to 1993 (USGS 1911-1912, 1945-1968 reviewed in 1993, 1989-1992). Assuming the hydrograph is similar on the South Fork, impact of severe dewatering on grayling observed in the Big Hole River is not likely to be an issue in the forks of the sun River.

Water temperature data from either fork is also extremely limited. Available temperature data suggests mean daily water temperatures most likely range between $55-65^{\circ} \mathrm{F}$ in summer months. Thermal tolerances of grayling are exceeded above $77^{\circ} \mathrm{F}$ (Lohr et al. 1996). In the Big Hole River, temperatures exceeded these levels in 5 of 7 drought years between 1988-1994 (Byorth 1994). Stable summer flows and the limited temperature data available suggest temperatures in the North and South forks will range within suitable limits for grayling. Thermographs will be deployed on both forks to further assess temperature regimes. 


\section{REINTRODUCTION AND MONITORING PROTOCOL}

Grayling will be stocked into the North and south forks beginning fall 1998 through the year 2001. Planting protocol will follow the 1995 guidelines established in the Fish, Wildlife and Habitat Management Framework for the Bob Marshall Wilderness Complex. Yearling and young-of-the-year (YOY) grayling will be supplied by USFWS Fish Technology Center in Bozeman and MFWP Bluewater or Big Springs State Fish Hatcheries with fish descended from wild fluvial Big Hole River stock. Recommended stocking rates are at densities of 350 per mile or 7,350 yearlings for the North Fork and 4,550 for the South Fork based on predicted mortality of 50 to $75 \%$. Stocking rates of yoy grayling should be equal to or greater than those of yearling plants. However, remoteness of the Bob Marshall Wilderness Area will make planting these numbers logistically challenging. stocking rates will depend on availability of fish, personnel and pack animals. It will be feasible to stock more smaller yoy grayling (mean length 2 inches September 1), than larger yearling grayling. Young of the year grayling will require less space and oxygen and thus more YoY fish can be transported per pack animal. However, YoY will most likely have higher mortality rates than yearling fish. Yearling grayling (mean length 6-10 inches) will require considerably more pack animals, thus stocking numbers may be limited. An estimated 400, YOY (2.0 inch) fish and 100 yearling $(6.0$ inch) fish can be transported per horse with good survival (MFWP Files). 
The North Fork grayling will be transported in aerated tanks by hatchery truck to the South Fork of the Teton trailhead, or the Route Creek trail access. Thereafter, grayling will be placed in aerated bags, placed in coolers, and transported by pack animals to the North Fork. From the South Fork of the Teton trailhead, fish would be transported over Headquarters Pass to the North Fork, just upstream from Gates Creek. Grayling will then be distributed up and down stream. From the Route Creek trailhead, grayling will be transported over Route Creek pass to the North Fork near Wrong Creek and distributed up or down stream. Location of distribution sites will depend on how long fish can be held without excessive stress. Fish will be tempered to river temperatures and a sample of grayling will be held in a live car to assess survival.

On the South Fork, fish will be transported from the hatchery to Benchmark and distributed up or downstream by mules, horses or raft. A raft may be used to distribute fish downstream reducing the number of pack animals. The raft would then be packed by horse or mule upstream to Benchmark. Yearling grayling should be released immediately after runoff in late June or early July. YOY should be stocked in mid-late August to allow sufficient acclimation before winter.

Transporting grayling via helicopter could be a future option if approved by the USFS and Bob Marshall Wilderness Complex Management Team. An additional option may be using fertilized eggs and instream incubators instead of planting yoy or yearling grayling. Instream incubators consist of 5 gallon plastic buckets 
5 gallon plastic buckets with perforated egg trays. The incubators are placed in the stream and water flows through the perforated trays allowing egg development. The success of instream incubators has not been tested for fluvial grayling, however, if successful, would be less labor intensive and would not require large numbers of pack animals.

Monitoring

Thorough monitoring of reintroductions is necessary to maximize the probability of success and to document factors that may hinder or help future reintroductions. Monitoring will continue at least through 2006 unless data dictate that successful establishment of a self-sustaining population is unlikely. Monitoring until 2006 will allow MFWP to determine if natural reproduction from progeny of stocked fish is equal or exceeding annual mortality for three consecutive years.

Snorkeling, hook and line, and creel surveys will be employed as the primary monitoring tools to document survival, dispersal, population density, and fish community composition.

Grayling population estimates will be incorporated in the traditional MFWP sections in the North and South forks in late July. This will require no additional man power or time. On the North Fork an average 8.6 angler days and 2.6 working days, and on the South Fork on average 10.0 angler days and 3.0 working days is needed to complete these estimates (Bill Hill, MFWP, Personal Communication).

Snorkeling and creel surveys will determine survival, 
distribution, and identify important habitats. Snorkeling will be done at randomly distributed sites on both forks. Five, 1 mile sites will be selected per fork. Snorkelers can cover 1 mile per hour (Bill Hill, MFWP, Personal Communication). Two snorkelers and one recorder will require approximately 2 days per fork. These surveys should be done in mid-late summer or fall when water levels are low to increase efficiency. If snorkeling and creel surveys identify productive grayling habitats and survival, an additional one mile, hook and line`snorkeling mark-recapture population estimate may be completed on each fork upstream from the MFWP current monitoring sections. These estimates would not be done until evidence from creel surveys, snorkeling, or the current monitoring efforts indicate that planted grayling have survived and taken up residence in the streams. These estimates will take 3 additional days on each fork with similar angler days (approximately 9 angler days on the North Fork and 10 angler days on the South Fork, (Table 2)).

A voluntary creel survey should be coordinated to assess survival, growth, and fish distribution. MFWP and USFS would like to coordinate with local outfitters and guides to gather creel information. Monitoring efforts will be conducted in a manner to minimize disturbance to wildlife, and be least intrusive to recreational users. Additional research and monitoring projects will be adapted as need arises.

Annual spring monitoring will continue on Gibson Reservoir to detect presence and relative abundance of grayling and monitor 
reservoir rainbow trout populations. Electrofishing, gill netting, fish traps, or creel surveys will be the primary monitoring techniques. Electrofishing has been used from 1994-1997 to monitor populations, and the presence of whirling disease at the confluence of the North and South Forks.

Table 2. Arctic grayling monitoring efforts for the North Fork (NF) and South Fork (SF) of the Sun River.

\begin{tabular}{|c|c|c|c|}
\hline TASK & $\begin{array}{l}\text { DURATION } \\
\text { Average \# } \\
\text { Days }\end{array}$ & ANGLER DAYS & TIME \\
\hline $\begin{array}{l}\text { Traditional } \\
\text { MFWP } \\
\text { Estimates }\end{array}$ & $\begin{array}{ll}\text { NF } & 3.0 \\
\text { SF } & 3.0\end{array}$ & $\begin{array}{ll}\text { NF } & 9.0 \\
\text { SF } & 10.0\end{array}$ & Late July \\
\hline $\begin{array}{l}\text { Additional } \\
\text { Grayling } \\
\text { Estimates }\end{array}$ & $\begin{array}{ll}\text { NF } & 3.0 \\
\text { SF } & 3.0\end{array}$ & $\begin{array}{ll}\text { NF } & 9.0 \\
\text { SF } & 10.0\end{array}$ & $\begin{array}{l}\text { Mid-Late } \\
\text { Summer } \backslash F a l l\end{array}$ \\
\hline $\begin{array}{l}\text { Grayling } \\
\text { Snorkeling } \\
\text { Surveys }\end{array}$ & $\begin{array}{ll}\text { NF } & 2.0 \\
\text { SF } & 2.0\end{array}$ & $\begin{array}{l}0 \\
0\end{array}$ & $\begin{array}{l}\text { Mid-Late } \\
\text { Summer } \backslash \text { Fall }\end{array}$ \\
\hline Totals & $\begin{array}{ll}\text { NF } & 8.0 \\
\text { SF } & 8.0\end{array}$ & $\begin{array}{ll}\text { NF } & 18.0 \\
\text { SF } & 20.0 \\
\end{array}$ & \\
\hline
\end{tabular}

\section{CONCLUSIONS}

Analysis of social and biological issues indicates that an introduction of grayling into the North and South forks of the Sun River is feasible and should be pursued. The assistance of the local communities in identifying issues and their support for the reintroduction will be a key in the success of the program. The primary social concern included the impacts of the Endangered Species Act on public and private resource use. Concerns regarding this issue should be allayed by a recent cooperative agreement 
between USFWS and MFWP, which will allow the reintroduction program to continue without the likelihood of classification as endangered. Much about the biological suitability of the forks of the Sun River for grayling is unknown. While cursory analysis of habitat, temperature, and flow data indicate the potential for establishment of a self-sustaining population, this will best be answered by a well-planned reintroduction followed by thorough monitoring.

The key to conserving Montana's unique stock of fluvial Arctic grayling is maintaining the Big Hole River population at maximum stable levels while establishing populations into suitable waters. Our goal of establishing a self-sustaining population in the upper forks of the Sun River will be an important step in preserving Montana's fluvial Arctic grayling. 


\section{IITERATURE CITED}

Bachman, R. A. 1982. Foraging behavior of free-ranging wild and hatchery brown trout in a stream. Transactions of the American Fisheries Society 113:1-32.

Byorth, P. A. 1994. Big Hole River Arctic grayling recovery project: Annual monitoring report 1993. Submitted to: Fluvial Arctic Grayling Workgroup. Montana Department of Fish, Wildlife, and Parks, Bozeman.

Byorth, P. A. 1995. Big Hole River Arctic grayling recovery project: Annual monitoring report 1994. Submitted to: Fluvial Arctic Grayling Workgroup. Montana Department of Fish, Wildlife, and Parks, Bozeman.

Byorth, P. A. 1997. Big Hole River Arctic grayling recovery project: Annual monitoring report 1996. Submitted to: Fluvial Arctic Grayling Workgroup. Montana Department of Fish, Wildlife, and Parks, Bozeman.

Byorth, P. A. and J. P. Magee. 1996. Big Hole River Arctic grayling recovery project: Annual monitoring report 1995. Submitted to: Fluvial Arctic Grayling Workgroup. Montana Department of Fish, Wildlife, and Parks, Bozeman.

Kaya, C. M. 1992a. Review of the decline and status of fluvial Arctic grayling (Thymallus arcticus), in Montana. Proceedings of Montana Academy of Sciences 52:43-70.

Kaya, C. M. 1992b. Restoration of fluvial Arctic grayling to Montana streams: assessment of potential of streams in the native range, the upper Missouri River drainage above Great Falls. Prepared for: Montana Chapter of the American Fisheries Society, Montana Department of Fish, Wildlife, and Parks, U. S. Fish and Wildlife Service, U. S. Forest Service.

Lohr, S. C., P. A. Byorth, C. M. Kaya, and W. P. Dwyer. 1996. High temperature tolerances of fluvial Arctic grayling and comparisons with summer water temperatures of the Big Hole River, Montana. Transactions of the American Fisheries Society $125: 933-939$.

Magee J. P. and P. A. Byorth. 1998. Big Hole River Arctic grayling recovery project: Annual monitoring report 1997. Submitted to: Fluvial Arctic Grayling Workgroup. Montana Department of Fish, Wildlife, and Parks, Bozeman.

Montana Department of Fish, Wildlife, and Parks. 1996. Montana statewide angling pressure, 1995. Montana Fish, Wildlife, and Parks, Bozeman. 
Montana Fluvial Arctic Grayling Workgroup. 1995. Montana fluvial Arctic grayling restoration plan. Montana Fish, Wildlife, and Parks, Helena.

Shepard, B.B. and R.A. Oswald. 1989. Timing, location and population characteristics of spawning Montana Arctic grayling (Thymallus arcticus montanus (Milner)) in the Big Hole drainage, 1988. Report to: Montana Department of Fish, Wildlife and Parks; Montana Natural Heritage Program - Nature Conservancy; and U.S. Forest Service, Northern region.

U. S. Fish and Wildlife Service. 1991. Endangered and threatened wildlife and plants; animal candidate review for listing as endangered or threatened species, notice of review. Federal Register 56(225):58804-58836.

- 1993. Endangered and threatened wildlife and plants; 90day finding and commencement of status review for a petition to list the fluvial population of the Arctic grayling as endangered. Federal Register 58(11):4975-4976.

- 1994. Endangered and threatened wildlife and plants; finding on a petition to list the fluvial population of the Arctic grayling as endangered. Federal Register $59(141): 37738$.

- 1996. Plant and animal notice of review. Federal Register $61: 7596$.

U. S. Geological Survey. 1989. Water resources data, Montana, water year 1988. U. S. Geological Survey Water-Data Report MT-88-1. Helena, MT.

- 1990. Water resources data, Montana, water year 1989. U.S. Geological Survey Water-Data Report MT-89-1. Helena, MT.

- 1991. Water resources data, Montana, water year 1990. U.s. Geological Survey Water-Data Report MT-90-1. Helena, MT.

- 1992. Water resources data, Montana, water year 1991. U.s. Geological Survey Water-Data Report MT-91-1. Helena, MT.

- 1993. Water resources data, Montana, water year 1992 . U.S. Geological survey Water-Data Report MT-92-1. Helena, MT.

1994. Water resources data, Montana, water year 1993. U.s. Geological survey Water-Data Report MT-93-1. Helena, MT.

1995. Water resources data, Montana, water year 1994. U.s. Geological survey Water-Data Report MT-94-1. Helena, MT. 
1996. Water resources data, Montana, water year 1995. U..s. Geological Survey Water-Data Report MT-95-1. Helena, MT.

Vincent, E. R. 1987. Effects of stocking catchable-sized hatchery rainbow trout on two wild trout species in the Madison River and O'Dell Creek, Montana. North American Journal of Fisheries Management 7:91-105.

Vincent, R. E. 1962. Biogeographical and ecological factors contributing to the decline of Arctic grayling, Thymallus arcticus Pallas, in Michigan and Montana. Ph.D. Thesis. University of Michigan, Ann Arbor. 